Article

\title{
Transforming Losses-A Major Task of Spiritually Integrated Psychotherapy
}

\section{Eckhard Frick}

Professor of Spiritual Care, Interdisciplinary Centre of Palliative Medicine, Munich School of Philosophy, University of Munich, Kaulbachstrasse 31a, 80539 Muenchen, Germany;

E-Mail: efrick@med.lmu.de; Tel.: +49-89-7095-7937; Fax: +49-89-7095-7929

Received: 1 September 2011; in revised form: 23 November 2011 / Accepted: 24 November 2011 / Published: 25 November 2011

\begin{abstract}
Since Freud's "Mourning and Melancholia", bereavement encompasses the dilemma between continuing versus relinquishing bonds to deceased persons. Mourning is the process of symbolizing the loss, of making sense by facing the conflict between the absence of the lost object and the continuing presence of an emotional relationship to that which is lost. Furthermore, mourning is not limited to bereaved persons but also concerns dying persons and, in a broader sense, our whole symbolic life which is playful coping with a rhythm of absence and presence. True consolation connects the individual and the archetypical mourning. Spiritually integrated psychotherapy may accompany this process by amplification. Christian mysticism takes its starting point from the experience of Jesus Christ's lost body, and this may be understood as a model of spiritual transformation.
\end{abstract}

Keywords: mourning; living symbol; mysticism; spiritually integrated psychotherapy

\section{Introduction}

The work of mourning does not only cope with situations of bereavement but also with any loss "of some abstraction which has taken place of one, such as fatherland, liberty, an ideal, and so on" [1]. Taking Freud's seminal text as a starting point, this paper argues that our whole life encompasses a work of mourning and that spiritually integrated psychotherapy accompanies the patient's life long coping process and his or her searching for meaning, especially by means of living and grief transforming symbols. 
Spirituality may be understood as a search for the sacred, especially in times of stress when spiritual coping helps conserve the sacred. In the practice of psychotherapy, spirituality may be a part of the problem or a part of the solution or even both.

"Spirituality is a therapeutic fact of life. The reality is we cannot divorce spirituality from the therapeutic process. The choices are to be explicit about it, to tiptoe around it, or to reduce it to something else. [...] Like it or not, spirituality is fully interwoven into human experience, including what takes place in the therapy room. The question, then, isn't whether to address spirituality in psychotherapy. Therapeutic neutrality toward spirituality is impossible. As with every other dimension of behavior, spirituality will be shaped one way or another by the therapy process. The real question is how we choose to address spirituality in psychotherapy" [2].

Or, with the words Carl Gustav Jung carved above the door of his house, VOCATUS ATQUE NON VOCATUS, DEUS ADERIT (Whether called or not, God will be there). We shall now examine how psychotherapy addresses situations of mourning and, more fundamentally, how the work of mourning is a crucial aspect of spiritual life and of spiritually integrated psychotherapy.

The focus of this paper is individual psychotherapy in the context of collective mourning processes. That is why, psychoanalytic reflection is supplemented by the mystical approach to the void and by authors who bring together psychoanalysis and mysticism in the context of mourning.

\section{Our Whole Life Is a "Work of Mourning"}

Everything starts with Freud's seminal text "Mourning and melancholia" [1] where we find in statu nascendi not only his (second) theory of mental structure [3] but also later developments of post-Freudian thinking such as attachment theory, psycho-analysis of narcissism / self-psychology, and object-relations theory. "Mourning and Melancholia" was originally part of a meta-psychology. Some other chapters seem to be destroyed by Freud himself [4]. It is true that many contemporary readers shrink back from his drive-psychology's physicalist language. Freud himself admits that his energetic and economic terminology is not entirely satisfying. We must, consequently, reconstruct Freud's thought using more recent authors who more or less refer to him. Freud describes the work of mourning as follows:

"The testing of reality, having shown that the loved object no longer exists, requires forthwith that all the libido shall be withdrawn from its attachments to this object. [...] The task is now carried through bit by bit, under great expense of time and cathectic energy, while all the time the existence of the lost object is continued in the mind. Each single one of the memories and hopes which bound the libido to the object is brought up (eingestellt) and hyper-cathected, and the detachment of the libido from it is accomplished. Why this process of carrying out the behest of reality bit by bit, which is in the nature of a compromise, should be so extraordinarily painful is not at all easy to explain in terms of mental economics. It is worth noting that this pain [Schmerzunlust] seems natural to us. The fact is, however, that when the work of mourning is completed the ego becomes free and uninhibited again."

The testing of reality "shows" that the loved object no longer exists: This "showing" is not absolute, it is, on the contrary, impeded by all forms of defenses. Freud, in his physicalist language, speaks about the libido "bound to the object": Reality-testing requires "that all the libido shall be withdrawn from its attachments to this object" although we "never willingly abandon a libido-position". 
What about the libido and what about its binding to the object?

Let us read the short text "On transience" [5], a remarkable "summer-walk through a smiling countryside", published in war-times one year before "Mourning and Melancholia" (but actually written some months after it). Freud is "in the company of a taciturn friend and of a young but already famous poet". The young poet, probably R.M. Rilke, was "disturbed by the thought that all this beauty was fated to extinction". Freud anticipates what he will write about mourning and tells us:

"But why it is that this detachment of libido from its objects should be such a painful process is a mystery to us and we have not hitherto been able to frame any hypothesis to account for it. We only see that libido clings to its objects and will not renounce those that are lost even when a substitute lies ready to hand. Such is mourning."

Note that mourning in this text is not severance of attachment but continuity of bonds. How can we distinguish the mere defense against the reality of loss and this desire of continuity?

In this text, Freud defines libido as "Liebesfähigkeit" (capacity to love). He presumes that we come to this life with a certain amount of narcissistic libido, i.e., libido turned towards the ego. When we withdraw libido from the ego and invest it in the objects those objects are somehow integrated in our ego. Conversely, after destruction or loss of objects, libido becomes free and returns to the ego.

Consequently, we have now reconstructed a first and simple meta-psychological model: Investment of libido in objects means that the ego loosens the narcissistic libido and that those objects become somehow part of the ego. Conversely, after destruction or loss of the objects and loss of the libido's point of contact, narcissistic libido will be tightened up or re-invested in other objects.

Freud uses a special concept for the libido's investing or "clinging": "Besetzung" (occupation). The Standard Edition translates by "cathexis". This nice Greek term is composed by "hexis" (having) and "kata" (under/according to). It is true that we hold tight whom or what we love and that we grasp even with more energy when we are about to lose it.

Freud does not yet postulate a "death drive". He considers a sexual drive in a broad sense, libido, which can 'cathect', or invest, in an 'object' (the site of satisfaction). The ego is a kind of reservoir of all libido, origin of cathexes to objects in the outside world as well as to representations of objects in the internal world. It is true that Freud's early mourning theory understands "the loss of a love object as a temporary disruption of the mourner's narcissism" [6]. What he calls "ego" in his theory of narcissism will be renamed "self" by post-Freudian authors.

Now we may have a second look on the Mourning \& Melancholia quotation.

"The testing of reality, having shown that the loved object no longer exists, requires forthwith that all the libido shall be withdrawn from its attachments to this object".

The object has been destroyed by death or another loss. Reality testing reminds the bereaved person of this fact and commands the withdrawal of attachment against a resistance demanding a particular effort.

"[...] The task is now carried through bit by bit, under great expense of time and cathectic energy, while all the time the existence of the lost object is continued in the mind".

Despite the knowledge of facts, libido is still clinging to the object (cathexis) and this ongoing cathexis is continued by the object's mental presence. There is an inner conflict between reality testing and emotional ties. Its resolution requires time and energy. 
"Each single one of the memories and hopes which bound the libido to the object is brought up (eingestellt) and hyper-cathected, and the detachment of the libido from it is accomplished".

Notice that in this sentence every philosopher will discover a category mistake: cathexis (binding of libido), hyper-cathexis, and detachment are physical terms. Memory and hope, on the contrary, are mental terms. Slipping from one category to the other is philosophically unsound.

The work of mourning consists in singularizing, bringing-up and intensifying (hyper-cathexis) of memories and hopes as a prerequisite of detachment. Paradoxically, the work of mourning is not a process of piecemeal fading away.

This paradoxical intensification is accompanied and expressed by the experience of pain:

"Why this process of carrying out the behest of reality bit by bit, which is in the nature of a compromise, should be so extraordinarily painful is not at all easy to explain in terms of mental economics. It is worth noting that this pain [Schmerzunlust] seems natural to us. The fact is, however, that when the work of mourning is completed the ego becomes free and uninhibited again."

After this last crescendo of suffering, the work of mourning seems to be "completed". But this is only one part of the story.

Let us see how contemporary psychoanalysis and attachment theory deal with Freud's theory.

Volkan differentiates two aspects of the German term "Trauer" used by Freud: The painful grief reaction and the more silent mourning process. "Trauerarbeit" (grief work) in the first meaning of emotional disclosure and detachment requires that the bereaved "confront and express their feelings and reactions" [7]. Some authors think that the therapist should compel bereaved persons to express sadness, "in the belief that the abreaction of suppressed affect is at the core of successful treatment" [8]. In empirical studies, there is little evidence that induced disclosure of emotions is effective in coping with bereavement [7].

"Uncomplicated grieving may be seen as nature's exercise in loss and restitution" [9]. However, the "burial" of mental images (of the lost person or thing) does not parallel the physical loss. It is, on the contrary, a long process which will be completed when the bereaved person makes the mental representation of the lost person or thing "futureless" [10], when the images of the lost item are no longer utilised to respond to the mourner's wishes.

How can we understand the mental images, the object representations? Volkan and Zintl [11] coined the term "psychic double" for every person who populates or once populated our world. This is a very understandable expression of what Melanie Klein calls "inner objects". Every "new" upcoming or happening bereavement challenges our experiences with good objects and may entail a regression toward more archaic, paranoid forms of relationship.

When someone important to us dies, the psychic double "remains hot" or even intensifies due to the separation (Freud's "hyper-cathexis"). "The work of mourning involves taking the heat out of the loss and cooling down, but not eliminating the psychic double", says Volkan.

Freud distinguishes normal mourning from melancholia. In melancholia, the lost object's shadow remains upon the ego, provoking troubles of self-esteem not observed in normal mourning. Melancholic identification means that the ego treats itself as if it was the object, with all the characteristics of hate and love. According to Volkan, we may distinguish normal mourning, melancholia, and perennial mourning: 'Normal' mourning, depression (melancholia), and perennial mourning. 
Using the term depression, Volkan follows Freud's vision of melancholic identification: "The mourner wants, unconsciously, to destroy (hate) the lost object's representation and feels guilty, whilst feeling obliged to hold on to (love) it because he/she still feels dependent on the representation of the lost object, as if it still has a 'future"'. Conversely, the 'normal' mourner examines the images of the disease and gets rid of the 'futureless' images. His or her unconscious identification with the beloved person is selective, concerns certain enriching functions of the lost object.

New and important is Volkan's concept of perennial mourners: They conserve the deceased person's mental representation in an "envelope" (introject) and have an illusion "that the deceased's images in this envelope can be brought back to life". This introject may remain unassimilated, it "relates to and stimulates the mourner's self-image" [12].

This new vision of perennial mourners' introjects is very important for understanding and treatment of traumatic losses: Losses without normal grief, e.g., without touching the dead body or losing it by extraordinary events such as a Tsunami, block the normal mourning process and may require psychotherapeutic help [13].

\section{Linking Objects May "Freeze" or Deblock the Mourning Process}

Volkan found that perennial mourners often used symbolic items, 'linking objects' which stop the process of mourning at a certain point. This freezing and postponing may hinder the individual from accomplishing the process or, on the contrary, permit completing the work of mourning. Linking objects may be (table 1):

Table 1. Linking objects according to Volkan.

\begin{tabular}{|l|}
\hline 1. Personal possession of the deceased \\
\hline 2. Gift or symbolic farewell note \\
\hline 3. Something the deceased used to extend his/her senses or body functions \\
\hline 4. Realistic or symbolic representation of the deceased \\
\hline 5. 'Last-minute object' \\
\hline 6. Created linking objects \\
\hline
\end{tabular}

The personal possession of the deceased, e.g., a watch, usually needs repair. The mourner becomes preoccupied about this repair. The object remains, however, unrepaired. The gift or symbolic farewell note is the last object given before a fatal accident, or before being killed as a soldier. Something the deceased used to extend his/her senses or body functions: May be a camera or another optical instrument or a mobile phone. Again, it may be broken, waiting for repair. Realistic or symbolic representation of the deceased: a photograph, a video, a tape recording, a painting or a text. 'Lastminute object': "something at hand when the mourner learned of the death or saw the deceased's body". Finally, the mourner may create linking objects by painting or other representations [12].

Linking objects are a frozen form of symbols, proto-symbols which may develop in the sense of symbolization. They have an "eerie" character, and there may be a "spiritual merging" with the dead person, including the fear to be influenced by the dead person who may actually come back into the mourner's life. Volkan distinguishes the highly symbolised linking object from Winnicott's "transitional object" which creates the intermediate space in the infant's development and from the 
fetish which is a rigid placeholder. Conversely, linking objects can initiate future mourning. In his "regrief therapy" Volkan used linking objects for beginning the mourning process as if the loss had just happened. Consequently, possessing linking objects, is a double-edged sword as far as personal growth is concerned.

Furthermore, enlarging individual psychology, he described mourning and frozen mourning processes in societies such as ex-Yugoslavia, South-Africa, and in the US [14].

A collective linking object may be a "chosen trauma" such as Serbian Prince Lazar's death during the Battle of Kosovo (June 28, 1389). In the approaches to the Serbs' war with Bosnian Muslims in 1990-1991 and again before the conflict with Kosovar Albanians in 1998, Slobodan Miloševič and his entourage 'reactivated' the Serbs' chosen trauma in order to distinguish Serb and non-Serb identities and in order 'legitimate' Serb violence against non-Serbs.

"As the six-hundredth anniversary of the Battle of Kosovo approached, the remains of leader captured and killed at the Battle of Kosovo, were exhumed. For a whole year before the atrocities began, the coffin traveled from one Serbian village to another, and at each stop a kind of funeral ceremony took place. This "tour" created a time collapse. Serbs were primed to react as if Lazar had been killed just the day before, rather than six hundred years earlier. Feelings, perceptions, and anxieties about the past event were condensed into feelings, perceptions, and anxieties surrounding current events, especially economic and political uncertainty in the wake of Soviet communism's decline and collapse. Since Lazar had been killed by Ottoman Muslims, present-day Bosnian Muslims - and later present-day Kosovar Albanians (also Muslims) — came to be seen as an extension of the Ottomans, giving the Serbian people, as a group, the "opportunity" to exact revenge from the group that had humiliated their large group so many centuries before. In this context, many Serbs felt "entitled" to rape and murder Bosnian Muslims and Kosovar Albanians" [15].

Trauma in wartime and ethnic conflicts are painful examples of the interdependency between collective and the individual suffering: The traumatized person is not alone with her/his pain, there are hundreds and thousands sharing the same experience. However, the traumatized person is terribly alone given that social comparison does not provide any consolation. Mal de muchos, consuelo de tontos (it is a fool's consolation the think everyone is in the same boat).

Linking objects occur at the individual as well as on the collective level. They are half-way between a non-symbolized and absurd beta-element and an alpha-element which is growing in a loving, understanding, containing relationship and which eventually entails reconciliation with the past. Bion told us that such a helpful relationship metabolizes and detoxifies beta-elements. We may call this process a symbolic transformation of trauma into "normal" mourning:

"The capacity to symbolize allows an individual to represent an experience mentally rather than concretely. In the aftermath of a trauma, painful and disturbing images, thoughts and feelings are often unable to be held in the mind in a way that distinguishes them from the actual reality of the event. They cannot be contained as memories. Instead these thoughts and images become concrete, live flashbacks that typically intrude into consciousness as a literal re-experiencing of the event. If the mental capacity is flawed or impaired in this way, there is also often an intrusion of the flashback experience into the body. This intrusion can take the form of psychosomatic illness" [16]. 
Accordingly, a collective linking object such as the Serb "chosen trauma" or an individual one, encompasses an ambivalent potential: it may provoke narcissistic identification, further trauma and violence, or, on the contrary, trigger the continuation of a "frozen" mourning process.

Returning to the individual dimension: When patients arrive in psychotherapy, they present us a symptom they want to get rid of or a problem they want to resolve. It is a great therapeutic chance to consider the symptom / problem as a kind of linking object, as an unfinished business, as a frozen mourning, requiring therapeutically accompanied re-grieving or, as the psychodramatist Jacob Moreno says, the therapeutic true second time which delivers the first time. Writing these lines, I am thinking about two men who brought their sexual symbol/problem to the therapy room: The first suffered from premature ejaculation. He had lost his father by a sudden cerebral stroke. His mother - he says hindered him from touching his father's dead body and from emotional grieving. His lacking capacity to enjoy pleasure and increasing excitation in a woman's presence may be understood as a linking object encompassing emotions such as sadness and grief but also anger, rebellion and selfassertiveness. The second analysand, conversely, was "delayed" at ejaculation. He was so orientated towards his partner's pleasure that he almost "forgot" his ejaculation. This young man had not lost his father by death but felt abandoned by him after his parents' divorce, he felt less loved and perceived by him than his (half-) brothers coming from his father's second marriage. But more than about all this, my analysand had to mourn the loss of one testicle which had to be extirpated after the diagnosis of cancer. The question of "balls" in professional and relational life was for a long time condensed in the lost testicle he missed after the operation. This loss, as the loss of other extirpated organs in cancer diseases, had to be mentalised during the analytic process.

\section{Mourning's Spiritual Dimension}

Kernberg resumes Freud's vision of the accomplished mourning by the term "identification" (with the lost object) while Freud reserves this term to the melancholic process and insists on the decathexis in normal mourning. Melanie Klein adds that normal mourning reawakens and resolves the depressive position in a process of reparation. Finally, Kernberg highlights the spiritual aspect of mourning. He proposes "a permanent relationship between the representation of self and the representation of the lost object, the combination of an intrapsychic presence of that object, and the awareness of its objective permanent absence" [17]. On the one hand, there is now no more forgiveness nor repair with the lost person. On the other hand, aspirations and values of the dead person may be experienced by the person in mourning as a mandate, a command: They become part of the mourner's superego as "highly personalized relations with the lost object". Libidinal investments are "not a zero sum capacity". On the contrary, "mourning interminably may become part of the increased capability for love and appreciation of life".

"[...] the expansion of moral values and ethical commitments related to the mandates that reflect the desires and aspirations of the person who died, whose life project was interrupted, are frequently a powerful stimulus to reparative action of the survivor providing a sense of purpose. They become, as mentioned before, ethical commands and aspired for ideals. Reparative processes, in short, expand into spiritual demands" [17]. 
The danger of the unaccomplished, frozen mourning process is, as Volkan says, a defensive "spiritual merging" between the mourning and the mourned person. However, when the reality of object loss is recognized, the power of the emotional and spiritual reality reflected in a permanent internalized relation with the lost object becomes an 'absent presence' as Kernberg quotes Sara Zac de Filc.

"The irresistible urge for reunion, the fantasy and concern over life after death, the expanding moral universe related to the mandate all combine in the expression of powerful religious impulses, whether they take the form of adherence to an established religious belief system, or are constructed individually as a painful yet indispensable aspect of spiritual existence and survival" [17].

Using the theoretical framework of attachment theory, Kernberg's spiritual bond and its structural consequences have been described as transformative process observed in securely attached mourners [18]. The lost person is "resurrected" in terms of "mentally represented legacy components (e.g., what would he have said, how would he have responded)", enriching "those mental representations of the lost person's legacy that carry substitute value" [19].

The analyst's role, his or her containing function during the mourning process, encompasses "the transference function of reinstating and maintaining that internalized relationship" with the lost object, while "bringing it to life in the relation with the analyst". According to Kernberg, this transference aspect reflects the double function of the mourning process - superego restructuring and maintaining the relationship [17]. Using Pargament's words, we can say that the analyst helps conserving the sacred in a situation of loss.

\section{Is Consolation Possible?}

In his criticism of religion, Freud often opposes scientific enlightenment and the soothing function of religion who feeds with empty promises, poor consolations, with hopes of a better world. This criticism basically concerns the illusion of narcissistic perfection and fulfilling of wishes [20]. Is a true consolation conceivable, a consolation which encompasses the work of mourning, i.e., the acknowledgement of a given object-loss? The answer will depend on the general theory of mourning: Does it consist in severance of attachment and redemptive replacement or is a continuity of bonds conceivable as Freud suggests in his dialogue with the silent as well as in a 1929 letter to Binswanger:

"Although we know that after such a loss the acute state of mourning will subside, we also know we shall remain inconsolable and will never find a substitute. No matter what may fill the gap, even if it be filled completely, it nevertheless remains something else. And actually, this is how it should be. It is the only way of perpetuating that love which we do not want to relinquish."

The Dual Process Model [18] endorses an "oscillation" between loss orientated and restoration orientated coping. This orientation entails emotional and cognitive commitments during the mourning process which is never entirely accomplished but encompasses, as the Dual Process Model shows, a relocated presence of the absent, a transformation of mental representations. This is true for bereaved persons but also for other losses, especially for the dying person's mourning called "travail du trépas" (transition work) [21].

De M'Uzan insists that we decipher the hastened death desire: 
"In fact, the dying person engages, under the terms of what I imagine like a kind of knowing of the species, in an ultimate relational experience. Whereas the bonds which attach him to the others are about to be finally severed, he is paradoxically raised by a powerful and somehow passionate movement".

The ultimate relational experience engaged by the dying person is paradoxical: "Although the dying person' s links to others are about to be untied, he/she over-invests objects, as a last attempt to assimilate unresolved issues" [22]. Des Rosiers considers life as "between two deaths": During the "first death" $[23,24]$, during analysis or finally during the travail du trépas, the "wonderful baby" is mourned. The dying process "can be seen as an attempt at an ultimate completion of the shift from narcissistic investment to object investment" [22].

True consolation cannot be provided by dead things but by living objects. Symbolically charged things may, however, convey this relational bond and restauration:

"The function of grave-stones, memorial monuments, pictures and photographs and works of art symbolically representing the lost person derive their consoling function from the assurance that the dead person is still out there, somewhere, in the external world" [17].

True and trustful consolation connects the individual and the archetypical mourning, deuil originaire (Racamier 1992). This archetypical layer is originally represented to us by the mother as first incarnation of world and Self [25] and transcends the narrow borders of our individual ego. This archetypical process of deuil originaire may be completed during an analytical process, entailing 'true' consolation. Helpful may be the Jungian "amplification" technique, i.e., confronting the individual experience with collective models such as myths, fairy tales, biblical texts.

The intensity of mourning corresponds, as a matter of fact, to the intensity of loving attachment bonds. Paradoxically, a secure "inner working model" does not entail a "clinging' continuity of bonds but an adaptive mentalizing capacity, corresponding to early experiences of coping with separation. What is true on the individual level also applies to the level of collective memory: Not the compulsive repetition of grief-signs but the work of memory transforms and heals bereaving experiences [26].

When we revive the infantile depressive position we do not only revive an individual experience but also a collective, as C.G. Jung puts it, an archetypical one:

"The manic-depressive and the person who fails in the work of mourning, [...] have this in common, that they have been unable in early childhood to establish their internal 'good' objects and to feel secure in their inner world. They have never really overcome the infantile depressive position. In normal mourning, however, the early depressive position, which has become revived through the loss of the loved object, becomes modified again, and is overcome by methods similar to those used by the ego in childhood. The individual is reinstating his actually lost loved object; but he is also at the same time re-establishing inside himself his first loved objects-ultimately the 'good' parents-whom, when the actual loss occurred, he felt in danger of losing as well. It is by reinstating inside himself the 'good' parents as well as the recently lost person, and by rebuilding his inner world, which was disintegrated and in danger, that he overcomes his grief, regains security, and achieves true harmony and peace" [27].

Volkan's studies show that freezing of mourning processes may occur not only at an individual but also at collective or a national level. Collective "linking objects" are as much obstacle to accomplished mourning as a starting point for re-grieving and new libido, new capacity of love. 
As in the classical Greek tragedy, true consolation does not consist in a narcissistic identification with my personal ego-ideal. True cathartic consolation is depersonalized, links my destiny to the hero's destiny who incarnates the human condition. This "desire-cathexis", according to Freud part of the mourning process, connects personal and archetypical mourning.

\section{Living Symbols Require a Work of Mourning}

Sym-ballein in Greek means to put or to throw together. When friends separated, they broke a bowl or a coin of money. When they met again (or their children), the joined pieces not only "signified" unity, they made unity.

According to Jung, a symbol is more than a sign which may be explained, verbalized, decoded. Deciphering "kills" a symbol which is "the best expression of a relatively unknown cause", better than our explanations or verbalizations. The symbol is the joint of two (separated, opposed) realities, and it generates a third which is beyond the original opposition ("transcendent" function of the symbol). "Perhaps the central task of mourning is to make sense of the conflict between the absence of the lost object and the continuing presence of an emotional relationship to that which is lost" [28].

My thesis is that every living, transformational symbol requires an absence and, in a certain sense, a work of mourning, of sense and meaning making. Our whole symbolic life which is playful coping with a rhythm of absence and presence. Freud's grandson Ernst [29] repeated this rhythm of absence and presence with a reel of thread: "Fort - da" (away - here):

"Occasionally, however, this well-behaved child evinced the troublesome habit of flinging into the corner of the room or under the bed all the little things he could lay his hands on, so that to gather up his toys was often no light task. He accompanied this by an expression of interest and gratification, emitting a loud longdrawn-out "o-o-o-oh" which, in the judgment of the mother (one that coincided with my own), was not an interjection but meant "go away" (fort). I saw at last that this was a game, and that the child used all his toys only to play "being gone" (fortsein) with them. One day, I made an observation that confirmed my view. The child had a wooden reel with a piece of string wound round it. It never occurred to him, for example, to drag this after him on the floor and so play horse and cart with it, but he kept throwing it with considerable skill, held by the string, over the side of his little draped it, so that the reel disappeared into it, then said his significant "o-o-o-oh" and drew the reel by the string out of the cot again, greeting its reappearance with a joyful " $D a$ " (there). This was, therefore, the complete game, disappearance and return, the first act being the only one generally observed by the onlookers, and the one untiringly repeated by the child as a game for its own sake, although the greater pleasure unquestionably attached to the second act".

By repeating the turning-point of this rhythm in both senses (absence $\leftarrow \bullet \rightarrow$ presence), Ernst acquires a symbolic self-empowerment, a playful trial of the unavoidable absence-and-presencerhythms linked with his young life's forthcoming losses. According to Freud, his grandson's game is for coping with powerlessness and passivity: passive in the first place,

"Overtaken by the experience", he now "brings himself in as playing an active part, by repeating the experience as a game in spite of its unpleasing nature. This effort might be ascribed to the impulse to obtain the mastery of a situation (the power instinct)". Freud adds another interpretation: The "gratification of an impulse of revenge suppressed in real life but directed against the mother for going 
away": "Yes, you can go, I don't want you. I am sending you away myself." Some years later, Ernst throw on the floor a toy and to say "Go to the war!". It seems evident, that he is coping with his father's absence as a soldier of World War I.

Freud's grandson's symbolic game may be interpreted as a tried mastery when facing the rhythm of presence and absence. Living symbols which produce libido, energy, as Jung says, are quite different from signs and proto-symbols in the sense of Volkan's linking objects.

They come forth of a liberating ritual, a mourning which is at the same time accepting the loss and opening a space for transformation, for the ongoing game.

Jung's distinction between a "killed" or "dead" symbol and a living one has an equivalent in Hanna Segal's distinction between "symbolic equation" and "symbolic representation". When asking patient "A" why he stopped playing violin, this young man suffering from schizophrenia "replied with some violence, 'Why, do you expect me to masturbate in public?'. Mr A had identified violin and penis in a concretistic manner. Conversely, "another patient, B, dreamed one night that he and a young girl were playing a violin duet. He had associations to fiddling, masturbating, etc." [30]. In distinction from A, B is able to distinguish violin and penis (symbolic representation).

Symbolic representations help us to cope with the loss of an (external) object. We learn that we do not possess it, that the mastery of the "o-o-o-oh" / " $D a$ " is limited. This acceptance of the uncontrollable external objects entail the possibility of an internal (symbolic) presence. "No breast-therefore a thought" [31]. Only when the infant can recognize the absence of the object she or he can either symbolize or think [28,32]. There is a strong difference between lost objects (which can be symbolized, e.g., in a therapeutic relationship) and objects which are gone (nameless dread according to Bion):

"Since the restoration of lost objects is preeminently a symbolic process, this cannot be achieved if absence remains in the unthinkable state of being 'gone' where the absence of the object is co-existent with the absence of a mind in which it can be known. In Bion's terms, there are only beta elements without a thinker to process them. This can only occur through the internalization of a container/contained apparatus which enables the development of alpha function and the formulation of mental contents into thoughts" [28].

If mourning expresses the conflict between the absence of the lost object and the continuing presence of an emotional relationship a symbol is born-in the mourner's mind, between analyst and patient, between conscious and unconscious:

"Projective identifications are gradually withdrawn and the separateness of the subject from the object becomes more firmly maintained. With that comes a greater awareness of one"s own psychic reality and the difference between internal and external. In such a situation the function of symbolism gradually acquires another meaning. Symbols are needed to overcome the loss of the object which has been experienced and accepted and to protect the object from one's aggressiveness. A symbol is like a precipitate of the mourning for the object" [32].

From a spiritual point of view, a loss or a traumatic experience such as the terrorist attack on 9/11, entails a violation, threat, or even loss of the sacred [2]. Paradoxically, such an experience may foster spiritual support and spiritual support seeking in order to conserve the sacred. However, critical life experience may trigger important spiritual struggles. Whether those struggles lead to growth or decline depends on the subject's ability to engage in spiritual transformation. By this term, Pargament refers to 
changes (1) "in the place of the sacred in the person's life" and (2) in the pathways the individual takes to the sacred" [2]. A first form of transformation consists in spiritual transitions / rites of passage permitting new roles by a re-working of linking objects, e.g., leaving the frozen and post-traumatic warrior-like identity. Additionally, revisioning the sacred encompasses a working-through of Godimages. Finally, centring the sacred is a cognitive and emotional process entailing fundamental changes. The current crises may help to recognise the limitations of current strivings and to the letting go of old values. This mourning of old values "creates a value and meaning vacuum. To fill that void, the individual looks to other sources of significance. When a spiritual transformation takes place, the shift is profound and may represent a change form 'playing God' to 'seeking God'" [2]. The process of spiritual transformation, as Pargament presents it, is not a synonym of goodness. It may entail losing or forgetting of yearnings for the sacred which will perhaps "smolder for a while beneath the ashes of disappointment and pain" [2]. Notwithstanding, this experience of "negativity' may reconnect itself with deep mystical pathways.

\section{Towards a Mystical Mourning of the Archetypical Loss}

We have seen that mourning deals with an "absent presence" which may be expressed in religious symbols. Christianity is, according to Michel de Certeau, "a lost-body discourse": "Christianity founded a discourse (the evangelical Logos) which offers ,consolation" for the loss of the body" [33]. In the context of his study about Jean-Joseph Surin, a XVIIth century Jesuit mystic, Certeau affirms that the name (Jesus Christ) is a substitute for his lost body, for the empty tomb. The name is the origin of another body, the church, and of the biblical text [34]. The experience of Pentecost requires the (lost) body's absence, the original spiritual experience of the void. The Eucharist (a sacramental "real presence" of Christ) is impossible without his real absence. The early Christian texts, especially St John and St Paul, call the Holy Spirit paráklētos: helper, advocate, consoler, comforter (facing an absence). Michel de Certeau calls mysticism-not only Christian mysticism-“utopical” because it does not "measure", pin down the spiritual neither scientifically nor psychologically. Although we want to locate God in what may be called a spiritual paradise, those attempts are missing their goal, leading to illusions or to non-places, ou-topoi such as the resurrected Christ's empty tomb. Certeau stresses a double attitude in mystical experience: One the one hand, it accepts this "spiritual utopia", on the other hand it opens a search for the sacred, a spiritual journey encompassing three moments:

1. The event, the kairós, the dotting and use of commas in the spiritual process: We identify such events later, post-hoc as sacred moments. We have seen God's back, says Certeau with allusion to Exodus 33:23: "Then I will take away my hand, and you shall see my back; but my face shall not be seen."

2. The epiphany, God's coming to history. He is the "always greater" as Christian and Islamic mysticism teach accordingly.

3. The apparition of the infinite which we need, which we cannot miss but which remains, nevertheless, unfathomable, incomprehensible, and unobjectivizable [35].

The infinite is an important name given to the sacred. As C.G. Jung puts it in his autobiography: "The decisive question for man is: Is he related to something infinite or not? That is the telling question of 
his life" [36]. Kierkegaard finds at the very beginning of The sickness unto death (chapter 1) the following definition of the human being as an ongoing, unaccomplished self-finding process:

"Man is a synthesis of the infinite and the finite, of the temporal and the eternal, of freedom and necessity, in short it is a synthesis. A synthesis is a relation between two factors. So regarded, man is not yet a self".

Michel de Certeau is not the only contemporary thinker who takes up Meister Eckhart's teaching about the void. There is a post-secular and post-Christian rediscovery of the hymn in Philippians 2:5-11:

"Let the same mind be in you that was in Christ Jesus,

who, though he was in the form of God, did not regard equality with God as something to be exploited,

but emptied himself, taking the form of a slave, being born in human likeness. And being found in human form,

he humbled himself and became obedient to the point of death-- even death on a cross.

Therefore God also highly exalted him and gave him the name that is above every name,

so that at the name of Jesus every knee should bend, in heaven and on earth and under the earth,

and every tongue should confess that Jesus Christ is Lord, to the glory of God the Father".

The words in verse 7, "emptied himself" (heautòn ekénōsen), gave rise to a veritable "kenotic" philosophy. Gianni Vattimo, e.g., argues that secularization brings kenosis to its accomplishment: "Incarnation is an archetypical occurrence of secularization" [37]. The weakness assumed by Jesus Christ in his incarnation is not a secondary phenomenon, a kind of concession made by the godhead to humankind's redemption. It is - granted the differences during the centuries of theological and philosophical thinking [38] - an aspect of the Christian god-image itself, a kind of God's individuation process as Jung accounts for in "Answer to Job" [39]. Consequently, the "split" between God and the world, between the sacred and the secular, has to be reworked. If incarnation is an archetypical occurrence of secularization secularization is an aspect of God himself, and still further: if creation of this worldly world is an archetypical occurrence of secularization, the process of demythologizing of this world begins in the Creator him/herself. As Vattimo notes, secularization is not a term in contrast with the essence of the Christian message, but rather is constitutive of it. The Logos', Jesus Christ's incarnation (the kenosis, the self-emptying of God), as an event both salvific and hermeneutical.

Jobin stresses the hermeneutics of this kenotic process as a major post-metaphysical understanding of the secularization, beyond the classical ontology of the Logos' nature and beyond the of s messianic consciousness inspired by the German idealism [38]. He reminds the "play" between mechanical structures which may provide an allowed clearance or, conversely, entail a dangerous void ("there is too much play in the steering"). The traditional vision of divine grace considers the human condition as empty, sinful, negative, in need of being "filled" with the redemptive gift of divine positivity. However, the kenosis presents another modality of divine grace, the self-emptying grace, kenotic redemption, the gift by void [40].

It is true that the classical kenotic discourse considers God's self-emptying as reverse of his glory and pleroma (fullness). However, if pleroma is not instrumentalized as a form of denial or of social institutions' self-glorification, kenosis provides an important and permanent critical potential regarding "full" forms of religious life, such as institutions, rituals, and social discourses, including post-modern 
highly individualized 'non-religious' discourses. This critical kenotic potential is particularly helpful when old or new spiritual discourses appear in social realities, e.g., in health care and psychotherapy. Facing post-modern sensibilities and discourses, the kenotic criticism helps "discern the spirits" as St Ignatius of Loyola formulates in according with the church's spiritual tradition. Ignatius differentiates the "good Angel" and the "evil" one, using the oscillation between consolation and desolation and between false consolation and sustainable consolation. Nowadays we have to discern a plurality of spiritualities, "various spirits", as Ignatius puts it (e.g., in Spiritual Exercises \#176). The challenge to find true and sustainable consolation remains the same.

Considering science fiction, fantasy, and fantastic horror, the post-modern sacred has been qualified as popular culture spirituality, as wholly profane, as a kind of profaning the traditional holy. "It is texts that are consumed [...] for their spiritual content, for an experience of the transcendent outside of the bounds of formal religious and spiritual traditions" [41]. Furthermore, mourning seems rather characteristic of post-modern longing for authenticity, manifesting itself as "sadness without object". Post-modern nostalgia is "the repetition that mourns the inauthenticity of repetition" [42].

Spiritually integrated psychotherapy supports the (post-)modern subject searching for the sacred, very often lost in spiritual transformation processes. It helps discern the nostalgic mourning without object and the true archetypical mourning, the mystical acknowledge of the void, the spiritual journey towards true and sustainable consolation.

One of the major theological objections against a broad understanding of spirituality in the public discourse, in research, and in psychotherapy is the following: When the sacred is completely undetermined and undefined, religion is up in the air, dissolved in individualism and without social and ethical commitment. It is true that spiritually caring psychotherapy deals with the undetermined (be it in the patient's or in the therapist's perspective). Authentically dealing with the undetermined does not refer to traditional answers, assignable contents, and collective forms of belief but to the authentic resources of the speaker [43]. Consequently, we need a discernment between different manners to address the undetermined. The psychoanalytic way has been explored by Wilfred R. Bion. He calls the unknown beyond our knowledge and beyond death "O":

"["O"] ... stands for the absolute truth in and of any object; it is assumed that this cannot be known by any human being... its presence can be recognized and felt, but it cannot be known. It is [however] possible to be at one with it.

That it exists is an essential postulate of science, but it cannot be scientifically discovered. No psycho-analytic discovery is possible without recognition of its existence, at-one-ment with it and evolution.

The religious mystics have probably approximated most closely to expression of experience of it... Its existence is as essential to science as to religion. Conversely, the scientific approach is as essential to religion as it is to science..." [31].

What Bion calls "Faith-in-O" is a non-religious "scientific state of mind", inspite of his religious allusions, especially to Christian and Jewish mystics. At-one-ment is Bion's expression of a symbol which produces reconciliation between presence and absence. 


\section{Conclusions}

Traditionally, we consider the work of mourning as an individual challenge to cope with negative life changing events such as bereavement, major disease, or harmful deceptions. However, collective reconciliation processes show that mourning and its incomplete, "frozen", forms are the prerequisite for successful social and psychological development and ongoing life. Furthermore, the mystical experience of the void, of lost physical "guaranties", and of detachment, offers a model for spiritual and psychotherapeutic processes. In light of these investigations on the personal level, perhaps we may better understand the difficult peace-making process in past and current political, social, and ethnic conflicts. Trauma is a particular poignant example for this analogy between individual and collective suffering and healing.

Mourning is greater than coping with bereavement. It is deeply rooted in the mystical acknowledgement of self-emptying, of a "kenotic" void. Consequently, the experiences of Christian mystics and of other mystical traditions can shed light on the spiritual quest of modern men and women, on the ambivalent potentials of spirituality, and on the risks of a spiritual quest.

Psychotherapy can accompany this quest. However, it does not fill up the patient's spiritual void. It supports his or her reappraisals, transformations, struggles which may be linked to unconscious conflicts. Even if therapists do not speak about their spirituality it will not be possible to remain in a third-person-perspective. In other words: patients help us discover our own spirituality.

\section{References and Notes}

1. Freud, S. Trauer und melancholie. In Gesammelte Werke; Freud, A., Bibring, E., Hoffer, W., Kris, E., Isakower, O., Eds.; Imago: London, UK, 1917e; Volume 10, pp. 427-446.

2. Pargament, K.I. Spiritually Integrated Psychotherapy. Understanding and Addressing the Sacred; Guilford: New York, NY, USA; London, UK, 2011.

3. Freud, S. Das ich und das es. In Gesammelte Werke; Freud, A., Bibring, E., Hoffer, W., Kris, E., Isakower, O., Eds.; Imago: London, UK, 1923b; Volume 13, pp. 235-290.

4. Bradbury, M. Classics revisited: Freud's mourning and melancholia. Mortality 2001, 6, 212-219.

5. Freud, S. On transience [vergänglichkeit]. In The Standard Edition of the Complete Psychological Works; Freud, A., Ed.; Hogarth Press Institute of Psychoanalysis: London, UK, 1916a; Volume 14, pp. 303-307.

6. Clewell, T. Mourning beyond melancholia: Freud's psychoanalysis of loss. J. Am. Psychoanal. Assoc. 2004, 52, 43-67.

7. Stroebe, W.; Schut, H.; Stroebe, M.S. Grief work, disclosure and counseling: Do they help the bereaved? Clin. Psychol. Rev. 2005, 25, 395-414.

8. Hagman, G. Beyond decathexis: Toward a new psychoanalytic understanding and treatment of mourning. In Meaning Reconstruction \& the Experience of Loss; Neimeyer, R.A., Ed.; American Psychological Association: Washington, DC, USA, 2001; pp. 13-31.

9. Volkan, V. A study of a patient's 're-grief work' through dreams, psychological tests and psychoanalysis. Psychiatr. Q. 1971, 45, 244-273.

10. Tähkä, V. Dealing with object loss. Scand. Psychoanal. Rev. 1984, 7, 13-33. 
11. Volkan, V.D.; Zintl, E. Life after Loss. The Lessons of Grief; C. Scribner's Sons: New York, NY, USA, 1993.

12. Volkan, V.D. The re-libidinalization of the internal world of a refugee family. Group Anal. 2003, $36,555-570$.

13. Bacqué, M.-F. Psychothérapie analytique des deuils post-traumatiques. Rev. Francoph. Stress Trauma. 2005, 5, 153-160.

14. Volkan, V.D. Not letting go: From individual perennial mourners to societies with entitlement ideologies. In On Freud's "Mourning and Melancholia"; Fioroni, L.G., Lewkowicz, S., Bokanowski, T., Eds.; International Psychoanalytic Association: London, UK, 2007; pp. 90-109.

15. Volkan, V. The Next Chapter: Consequences of Societal Trauma; University of Cape Town: Cape Town, South Africa, 2006.

16. Lemma, A.; Levy, S. The impact of trauma on the psyche: Internal and external processes. In The Perversion of Loss. Psychoanalytic Perspectives on Trauma; Whurr Publishers: London, UK, 2004; pp. 1-20.

17. Kernberg, O. Some observations on the process of mourning. Int. J. Psycho-Anal. 2010, 91, 601-619.

18. Stroebe, M.; Schut, H.; Boerner, K. Continuing bonds in adaptation to bereavement: Toward theoretical integration. Clin. Psychol. Rev. 2010, 30, 259-268.

19. Boerner, K.; Heckhausen, J. To have and have not: Adaptive bereavement by transforming mental ties to the deceased. Death Stud. 2003, 27, 199-226.

20. Westerink, H. Verwehte trauer. Ansätze zu einer freudschen theorie des trostes. Wege zum Menschen 2010, 62, 61-75.

21. de M' Uzan, M. Le travail du trépas. In De l'art à la mort; de M' Uzan, M., Ed.; Gallimard: Paris, France, 1976/1977; pp. 182-199.

22. Des Rosiers, P. Repetition of the mother-infant dyad and the process of dying in the psychotherapy of an hiv-positive man. J. Am. Acad. Psychoanal. 1999, 27, 191-204.

23. Leclaire, S. On tue un Enfant: Un essai sur le Narcissisme Primaire et la Pulsion de Mort; Seuil: Paris, France, 1975.

24. Racamier, P.C. Le génie des Origines. Psychanalyse et Psychoses; Payot: Paris, France, 1992.

25. Neumann, E. The Great Mother: An Analysis of the Archetype; Pantheon Books: New York, NY, USA, 1955.

26. Ricoeur, P. La mémoire, l'histoire, l'oubli; Seuil: Paris, France, 2000.

27. Klein, M. Mourning and its relation to manic-depressive states. In Essential Papers on Object Loss; Frankiel, R.V., Ed.; New York University Press: London, UK; New York, NY, USA, 1940/1994; pp. 95-122.

28. Colman, W. Mourning and the symbolic process. J. Anal. Psychol. 2010, 55, 275-297.

29. Freud, S. Jenseits des lustprinzips. In Gesammelte Werke; Freud, A., Bibring, E., Hoffer, W., Kris, E., Isakower, O., Eds.; Imago: London, UK, 1920g; Volume 13, pp. 3-69.

30. Segal, H. Notes on symbol formation. In The Work of Hanna Segal; Jason Aronson: London, UK, 1957/1981.

31. Bion, W.R. Attention and Interpretation. A Scientific Approach to Insight in Psycho-Analysis and Groups; Tavistock Publications: London, UK, 1970/1975. 
32. Segal, H. Dream, Phantasy and Art; Brunner-Routledge: New York, NY, USA, 1991.

33. Certeau, M.D. Heterologies. Discourse on the other; University of Minnesota Press: London, UK, 1986.

34. Certeau, M.D. Folie du nom et mystique du sujet: Surin. In Folle vérité. Vérité et vraisemblance de texte psychotique; Kristeva, J., Ed.; Seuil: Paris, France, 1979; pp. 274-304.

35. Certeau, M.d. L'expérience spirituelle. Christus 1970, 17, 488-489.

36. Jaffé, A. Memories, Dreams, Reflections by c.G. Jung; Vintage: New York, NY, USA, 1961/1989.

37. Vattimo, G. After Christianity; Columbia University Press: New York, NY, USA, 2002.

38. Jobin, G. Instituer l'évidement? Heuristique kénotique et positivité éthique. Laval Théol. Phil. 2011, 67, 69-86.

39. Jung, C.G. Antwort auf hiob. In Zur Psychologie Westlicher und Östlicher Religion (gw xi); Niehus-Jung, M., Hurwitz-Eisner, L., Riklin, F., Eds.; Rascher: Zürich, Switzerland, 1952/1963; Volume 11, pp. 385-506.

40. Jobin, G. Quand la faiblesse est donnée...Kénose et participation au temps du nihilisme. Et. Théol. Rel. 2010, 85, 323-346.

41. McAvan, E. The Postmodern Sacred: Popular Culture Spirituality in the Genres of Science Fiction, Fantasy and Fantastic Horror. Ph.D. Thesis, University of Murdoch, Perth, Australia, 2007.

42. Stewart, S. On Longing; Duke University Press: Durham, UK, 1993.

43. Nassehi, A. Spiritualität. Ein soziologischer versuch. In Spiritualität und Medizin. Gemeinsame Sorge für den Kranken Menschen; Frick, E., Roser, T., Eds.; Kohlhammer: Stuttgart, Germany, 2011; pp. 35-44.

(C) 2011 by the authors; licensee MDPI, Basel, Switzerland. This article is an open access article distributed under the terms and conditions of the Creative Commons Attribution license (http://creativecommons.org/licenses/by/3.0/). 